\title{
Digital Storytelling as a Tool for Fostering Reflection
}

\author{
Ali Hamilton \\ Rhodes College \\ Donald Rubin \\ University of Georgia
}

Michael Tarrant

University of Georgia \& University of Sunshine Coast

\section{Mikkel Gleason}

University of Georgia

\begin{abstract}
:
Reflection is an essential process for optimizing student learning outcomes in study abroad. Composing digital stories is a promising strategy for achieving high quality reflection. In this project we developed and explicated a rubric for assessing how students used the digital storytelling format to reflect on their study abroad experiences. We analyzed undergraduates' digital stories for evidence of both (a) disciplinary thinking in the field of sustainability and (b) intercultural understanding. Qualitative findings suggest that the digital story format offers students an opportunity to weave together digital artifacts that they often are already collecting. The process of creating digital stories both promotes and displays reflection. We also present an adapted rubric for assessing targeted learning outcomes manifest in digital stories produced by learners studying abroad. Applying the rubric revealed variability among students in achieving the aims of a digital story reflection assignment.
\end{abstract}

\section{Introduction}

The purpose of this project was to develop and explicate a rubric for assessing how students used digital storytelling to foster reflection about their study abroad experiences. Study abroad is increasingly recognized as a valuable component of the college experience, cultivating global citizenship, building competitive skills for the job market, and providing a host of other benefits (Twombly, Salisbury, Tumanut, Klute, 2012). While study abroad is almost universally touted as beneficial, we often do not know the degree to which the experience is transformational for all students (Churchill \& DuFon, 2006). Such information deriving from systematic evaluation is increasingly important as international educators strive to understand what makes a program successful in engendering targeted outcomes, as well as provide evidence for study abroad program effectiveness in the current climate that emphasizes measurable learning outcomes (Rubin \& Tarrant, 2017; Sutton, Miller, \& Rubin, 2007). But what are the mechanisms by which effective 
education abroad programs create conditions for transformative learning? Experiential learning is likely a necessary but not sufficient condition. Systematic or structured reflection about that experience is likely also necessary for high quality outcomes (Perry, Stoner, \& Tarrant, 2012). Disciplined reflection on international experience helps capture and crystalize the individual change that occurs (Walters, Charles, \& Bingham, 2017).

\section{The Role of Reflection in Study Abroad Learning Outcomes}

Strong scholarly consensus holds that critical reflection is key to enabling students to garner the full benefits from their overseas experience (Engle \& Engle, 2004; Lou, Vande Berg, \& Paige, 2012). In this respect, education abroad theory draws on more general theories of transformative adult learning (e.g., Mezirow, 1990; Pedersen, 2010). Transformative Learning Theory (TLT; Mezirow, 1990) places critical reflection front and center. Critical reflection involves challenging habits and expectations and reassessing one's own orientation to knowledge, attitudes, beliefs, and actions. TLT maps ten phases of perspective transformation that include experiencing a disorienting dilemma, examining one's assumptions, exploring new ways of knowing and behaving, and integrating those new ways into one's life (Mezirow, 1991, p. 168-169). In conventional classroom settings, the teacher sets up a disorienting dilemma for students to reflect on (Taylor, 2008). In education abroad, in contrast, the experience of a new culture or ecosystem poses disorienting dilemmas for students, and with the help of critical reflection, the study abroad class can then turn into the catalyst for transformative learning (Bell, Gibson, Tarrant, Perry, \& Stoner, 2014; Brockington \& Wiedenhoeft, 2009; Lange, 2004; Marx \& Moss, 2011; Savicki \& Price, 2015; Taylor, 2008; Trilokekar \& Kukar, 2011).

Sound education abroad pedagogy, then, does not leave student reflection to chance, but rather teaches students techniques and criteria for productive reflection. The most common instructional tool for encouraging student reflection is journaling in which students report and reflect on experiences throughout their experience by responding to directed and sequential questions (Ash \& Clayton, 2009; Bell et al., 2014). For example, Maximizing Study Abroad (Paige, Cohen, Kappler, Chi, \& Lassegard, 2002), the popular evidence-based student workbook, devotes an entire chapter and numerous exercises to journal writing. However, as digital technology continues to revolutionize higher education in general with the promise of greater efficiency and learner connectedness, instructors have adopted new tools to promote reflective learning. These include e-portfolios (Dietrich \& Olson, 2010) and blogging (Lee, 2011). Digital storytelling (DS) is another such technology with strong promise as a tool for engaging students in reflective learning. It has been fruitfully deployed in learning environments as diverse as medical education (Sandars \& Murray, 2009) and basic sciences (Genereux \& Tompson, 2009).

\section{Digital Storytelling (DS) as a Tool for Reflection in Study Abroad}

DS is typically a process of constructing a short video recording, created by a non-media professional, using images, video clips, audio, and/or narration to illustrate a story (Robin, 2008). Since the 1980s, cofounders Joe Lambert and the late Dana Atchley of the Center for Digital Storytelling have made DS an important part of the way in which people share, discuss, and reflect on their experiences (Lambert, 2012). After all, storytelling is fundamental to human understanding and social connection (Polanyi, 1985). In addition, when tasked with creating a digital story, students 
hone important 21st century skills including technology, digital, global, visual, and information literacy (Czarnecki, 2009; Jakes, 2006; Robin, 2008).

Recently, DS has been adapted to the study abroad context by making use of digital artifacts, such as pictures and videos that students are often already collecting during their travels (Buckner, 2015; Perry, Stoner, Schleser, et al., 2015). DS seems like a natural component for study abroad, since DS inherently involves experiential learning, engagement, and reflection-all key to study abroad learning outcomes. Perry et al. (2015) describe the pedagogical benefits of DS, suggesting that digital media can "provide the forum and space for students to reflect in a presentational form and, in this, more efficiently address changes in self-perception and/or attitude" (p. 327). Using digital artifacts may allow students to be more present in their reflection and more engaged in expressing it, compared with more conventional written reflections.

Research on the value of digital storytelling in connection with the study abroad experience is sparse. One study incorporated DS into a short-term study abroad experience with students traveling in Mexico. The program director concluded that, "by standing behind the camera or recorder, students slow down the parade of images they have already been exposed to, and create more thoughtful representations that emerge from their own dialogue with others" (Rodriguez, 2010, p. 230). Another study used DS to assess how a Fulbright-Hays study tour to China might impact teachers' level of intercultural competence (Walters, Green, Wang, \& Walters, 2011). Based on a 3-level holistic rubric, digital stories appeared to be more revealing of deeper reflection and intercultural competence, relative to written journal entries. Digital stories revealed meaningful selfperceived change in attitudes, beliefs, and behaviors over the course of the program. Among the most extensive reported uses of DS, 61 students participating in four different programs created digital stories (Bruckner, 2015). Rather than mere travelogues, their productions were supposed to show what they had learned from studying abroad, as if explaining to a prospective employer. Students received DS assessment rubric to guide their production. Based on data from 17 of the participants, DS appeared to promote reflection processes and the stories demonstrated learning outcomes. Others have also touted the pedagogical benefits of digital storytelling in education abroad (Li, Qu, \& Petersenn, n.d.; Sadik, 2008).

\section{Rubrics for Assessing Learning Outcomes of Study Abroad}

Aligned with the movement for authentic assessment, rubrics have long been used in education assessment for many purposes and domains (Montgomery, 2002; Reddy \& Andrade, 2010). While assessment rubrics vary along many dimensions, they do share certain key characteristics (Dawson, 2017). At minimum, rubrics provide clear evaluation criteria or dimensions of judgment, characterize the levels of quality for each criterion (often supplemented by annotated exemplars), and describe a rating process (which might include opportunities for formative evaluation prior to summative). Thus, rubrics provide structure, promote consistency and fairness for scoring, and offer efficiency in scoring student work. Rubrics can be created jointly by instructors and students, allowing for clarity and mutual ownership of standards. Through dissemination at the start of an instructional unit, rubrics can be used not only as a tool for assessment, but also for instruction. Many students favor rubrics because they provide clear guidance on expectations and provide a clear mechanism for feedback on work (Reddy \& Andrade, 2010). A few projects report rubrics used to assess learning outcomes of studying abroad. These include understanding of targeted concepts in 
ecology (McLaughlin \& Johnson, 2006) and in intercultural competence (McGury, Shallenberger, \& Tolliver, 2008). Buckner (2015) does offer a rubric for assessing the quality of DS arising from study abroad, but those criteria focus more on the aesthetics and genre characteristics of DS than on learning outcomes: e.g., "Music, if used, evokes the emotion of the story line and enhances the story. The emotion of the story is conveyed effectively through voice narration and images (15 pts)" (p. 144).

Many instructors at colleges and universities have adopted rubrics for both instruction and assessment through the Association of American Colleges and Universities' (AAC\&U) Valid Assessment of Learning in Undergraduate Education (VALUE) initiative (Rhodes, 2016). VALUE provides a variety of different rubrics, developed by experts in learning assessment "to determine whether and how well [students] are progressing toward graduation-level achievement in learning outcomes that both employers and faculty consider essential" (Association of American Colleges and Universities, 2014). Each VALUE rubric provides a means for measuring a different skill set such as critical thinking or academic writing. Using VALUE rubric results to inform instruction-for example, as a way to gauge optimal assignment difficulty (Sullivan \& McConnell, 2018)— has led to improved student learning.

In the present study we used rubrics as a means for assessing reflection manifested in the digital stories of study abroad participants. We created a VALUE-style multimedia rubric with the permission of AAC\&U. Our adaptation draws on categories from three different VALUE rubrics: Critical Thinking, Intercultural Knowledge and Competence, and Oral Communication (Association of American Colleges and Universities, 2014).

\section{Purpose of this Study}

Our goal was to establish a rubric-related tool that could capture how intensively students reflected on an academic focus of their programs through the medium of digital storytelling. Across the five different academic disciplines represented by these programs, the common core centered on the concepts of cultural progress and sustainability. Each program aimed to help students refine their conceptualization of what counts as progress through exposure to other environments and worldviews. At the end of the program, each student was asked to create a three-minute digital story to reflect on how his or her understanding of progress had changed.

Several research questions guided this study of digital stories and their use in the study abroad experience:

- Can DS be a useful tool in fostering student reflection about a study abroad experience?

- Can academic learning and intercultural understanding both be discerned through a digital story?

- Is the derived VALUE study abroad DS rubric a useful tool for assessing these digital stories? 


\section{Methods}

Context

This project was a non-invasive case study (Merriam, 2009). We worked with faculty members and staff of the Discover Abroad program at the University of Georgia (Bell et al., 2014; see also www.discoverabroad.uga.edu) to gain access to the digital stories. At the end of the experience, students uploaded their digital stories to the public platform YouTube. With clearance from the Institutional Review Board, the online multimedia products were treated as publicly available data.

The digital stories in this sample were produced by undergraduate students attending five different Maymester Discover Abroad overseas programs in 2015. Each program traveled within Australia, and all but one program also included travel within New Zealand. Each of the five programs had a different subject matter focus: Food and Nutrition, International Business, Animal Behavior, Biology and Animal Behavior, and Biology and Natural History. While the course content varied by class, all shared a common focus on issues of sustainability and analyzing the concept of "progress." Thus, comparisons across the five programs were not germane to this qualitative inquiry. Discover Abroad programs maximize experiential learning. The programs are designed so that students acquire academic content through a range of modules rather than lectures. Students go on various excursions, and respond to those excursions through debates, essays, quizzes, etc. The Discover Abroad commitment to transformational learning is expressed on its website:

To guide students to high personal standards of global citizenship, stewardship and intercultural competence. We believe that students themselves are significantly enriched not only academically but also personally by well-managed international experiences, and these are areas where we hope to have a significant impact on a student's own philosophy and values.

To foster reflection on the experiential learning, as part of their culminating assignment students were first asked to write a thematic essay answering the prompt, "Describe your understanding of progress and lessons (you have learned from this program) for a sustainable future." They were then to use the content of this thematic essay as the basis for creating a DS. Fellow students reviewed each other's thematic essays and gave feedback. During the program, the students were encouraged to keep journals, collect videos and images, and engage in ongoing reflection on the topics of sustainability and progress. They also participated in a DS production workshop where they learned technical skills and strategies such as storyboarding. The programs provided students with resources and tools to complete the assignment, such as video editing software. Students were required to complete their DS and upload it to YouTube within seven days of returning home.

\section{Sampling and Analysis}

To begin the analysis, we obtained links to all the digital stories that the students submitted from the five 2015 Maymester classes. We then analyzed each digital story, in a random order, according to the VALUE multimedia rubric that we adapted. After reviewing 25 digital stories, we found DS content largely repeated, with no new trends or themes, meaning we had reached saturation for purposes of qualitative analysis (Merriam, 2009). Consequently, we concluded our analysis at 25 digital stories. 
The VALUE Discover Abroad Digital Story Rubric appears in Appendix A. The rubric is not intended to be a comprehensive account of learning and skills accruing from study abroad, but rather a tool specifically tailored to the Discover Abroad instructional philosophy and learning objectives and the particulars of the progress reflection assignment. It drew from three different AAC\&U (2014) VALUE rubrics-Critical Thinking, Oral Communication, and Intercultural Knowledge and Competence. We adapted three subcategories from the Critical Thinking rubric to help assess disciplinary learning. We used three subcategories from the Intercultural Knowledge and Competence rubric that assessed the desired intercultural learning outcomes that faculty and staff at Discover Abroad hoped to bring about in their students. Finally, we modified three subcategories from the Oral Communication rubric to assess the kind of verbal skills that students should be using when creating a digital story. With this final category we hoped to assess how adept students were with using digital story as a communication medium. The final product is a VALUE study abroad multimedia rubric whereby students' digital stories are assessed on a scale of one to four in nine different subcategories, with a score of one representing the lowest quality (benchmark), two and three representing moderate quality (milestones) and four, the best (capstone).

Two raters who were familiar with the design and purpose of the rubric watched each digital story multiple times and transcribed sections of the narration to assist with analyzing the verbal content. As raters analyzed the digital stories, they worked to assess them according to the a priori categories that we established through the rubric, rather than looking for emergent themes as is common in qualitative studies (Merriam, 2009). Nevertheless, an iterative process to establish intercoder consensus resulted in reworking some rubric phrasing and establishing some rating conventions. The narrative that follows discusses themes corresponding to the revised rubric. The students in the discussion below were all given pseudonyms.

\section{Results}

Three major categories underpin the rubric and the ensuing analysis: disciplinary thinking, multimedia coherence, and intercultural understanding.

\section{Disciplinary Thinking}

Most students displayed proficiency in disciplinary learning, scoring $3 \mathrm{~s}$ and $4 \mathrm{~s}$ (out of a possible 4). The three subcategories in disciplinary/critical thinking on the rubric were (1) explanation of issue, (2) central message, and (3) conclusion. Students were able to skillfully describe the issue of progress and sustainability and also explain complexities associated with the issues. For example, in the opening narration of his digital story, Ryan described the characteristics of progress in U.S. terms (i.e., personal economic advancement and consumption), but also acknowledged, “one's understanding of progress can be different based on perspective." He illustrated this point by describing the way the Noosa community in Australia chose to manage economic growth and tourism through sustainable activity. Noosa was not interested simply in growing its economy through tourism, but rather in finding a way to promote tourism and preserve its natural environment through sustainability. Referring to the contrasting U.S. and Noosan points of view, Ryan said in his digital story, "I could definitely see both sides of the spectrum." Ryan displayed a nuanced and high level of understanding of the issue of progress — a focal disciplinary constructand was able to illustrate that sophisticated understanding in his digital story. 
Some students, however, did not address the issue of progress with similar insight. Rachel's digital story defined progress only in personal terms, rather than exploring the idea of progress as it pertained to the academic content about sustainability (e.g., "triple bottom line" reporting). Rachel defined progress as "moving through a process in order to reach goals" and "always moving forward." Rachel's goals for the program were to be more independent from her family, and by the class's end she said, "I have made more progress than I ever thought possible." While personal growth is undeniably an important part of the study abroad experience, this response suggested that Rachel did not critically consider the idea of progress from the point of view of the communities that she visited, which was the purpose of the excursions from the perspective of disciplinary learning.

Rubric scores for many students were low in the subcategory of conclusions, another constituent criterion of disciplinary thinking. In order to receive the highest score, students needed to draw a conclusion that was consistent with their central message, and to make a personal application to their life. Few students, however, seemed to communicate a newly evolved understanding of progress and sustainability in connection with their own life. Most seemed to express general feel-good notions about being more sustainable at home, or they compartmentalized their experiences as valuable, but not necessarily as something they could truly integrate into their life at home.

An example of a conclusion that stops short of this integration was found in Mark's digital story. Mark talked positively about his time in Australia and New Zealand and explained that he had reconsidered his view on "dominion vs. stewardship" of the natural resources around us. After showing a montage of breathtaking pictures of Australian landscapes, he flashed a picture of a treehugger and concluded his digital story by saying that though he is "far from hugging trees ... I will keep these lessons in mind as I return back to the consumer driven country we live in." Mark concluded his digital story with a video of him bungee jumping off a soaring bridge as he mentioned his impending return to North American consumerism. This sequence suggested that Mark understood and considered new perspectives but did not intend to integrate them into his life at home. It stops short of the transformative learning for which study abroad strives. Mark displayed a rather simplistic polarization: to be environmentally conscious is to be a caricatured tree-hugger.

In contrast to Mark, other students exhibited clearly transformative conclusions. Sally talked passionately about her program in Australia and New Zealand and described how her understanding of progress and sustainability was no longer "solely economic." While showing pictures of watermoderating showers and recycling tools (evidence of disciplinary learning), she described practical ways that she planned to integrate this new knowledge into her life, not only as a responsible citizen, but also as someone who was planning future political activity. Sally viewed her new knowledge as "weapons to help win the battle for sustainability and progress." Sally conceptualized how her new learning not only applied to her life as a citizen, but how it could also be integrated into her desired career path in public service.

\section{Multimedia Coherence}

In the major category of multimedia coherence there were three subcategories: (1) organization, (2) visual content, and (3) supporting material. Most students were able to organize various forms of 
media, including images, pictures, video clips, music, and others, into a cohesive presentation. Organization is an important criterion, since it enables a coherent thesis-driven exposition (as opposed to just an attractive collage, for example). The organization of the media generally followed the structure of the scripted narration and often (but not always) supported the narration. For example, when students described an excursion to Lady Elliot Island to learn about the Great Barrier Reef, they used images and videos from Lady Elliot Island to support this narration. This was appropriate and helped add visual representation, that is, evidence (Hocks, 2003). In several cases, however, students did not connect their visual content to the scripted narration and displayed, instead, a selection of pictures — albeit dramatic and aesthetically stunning — in seemingly random order during their digital story. The students who failed to connect the visual content to the narration missed an opportunity to support and add to the richness of their reflection.

Only one student displayed a sophisticated use of visual content. Ann used the metaphorical theme of "taking a leap" throughout her digital story. She presented this theme in a literal sense by showing videos of her leaping across rocks and jumping into the ocean. But she also presented the theme metaphorically as she described communities that stretched her understanding of progress. Ann's digital story showed many images of crossing bridges, jumping into the ocean, and using stepping stones to cross a stream. The images communicated the ways in which Ann felt she was taking leaps in her personal life, and also in bridging her understanding of new cultures. The sophisticated use of images added depth to Ann's digital story and allowed her to communicate her reflections in a powerful way.

\section{Intercultural Understanding}

The intercultural understanding domain was comprised of three subcategories: (1) cultural selfawareness, (2) other worldview frameworks, and (3) curiosity about other cultures. Most students seemed to broadly display cultural self-awareness in their digital stories, but fewer communicated about other worldviews, and fewer still displayed curiosity about other cultures. In many cases, students were able to identify how their own experiences contributed to shaping their perspectives. Eliza, for example, said, "Due to being raised in a comfortable urban setting, my initial opinion of progress was fixated more on the social and economic expansion of an area, as opposed to the environmental growth." Eliza thus connected her upper middle-class North American upbringing to her understanding of progress. This showed a cultural self-awareness as she contrasted her perspectives with the perspectives of the Australian and New Zealand people. Most students, like Eliza, were able to locate their perspectives in their experiences, but in contrast to Eliza, some made no mention of cultural biases and did not seem to reflect on the social forces that helped form their perspectives.

Lazaro also communicated a sophisticated processing of cultural identity and other worldviews. He explained that his understanding of progress came from his "various life experiences" and said that learning from the perspectives of people in other cultures brings "balance and equity." Lazaro described the ways Europeans devalued the perspectives of the Aboriginal people, who were actually very sophisticated in their understanding of sustainability. He said that for progress to be achieved "in a multi-diverse culture, then culture needs to be respected." Thus, Lazaro assigned value to diverse worldviews and perspectives and was advocating for a way to respect all of them. Few students matched the sophisticated reflection connecting progress and cultural relativism that Lazaro 
did, but many were able to identify worldviews that were different from their own and to see the complexity and value in those worldviews.

The subcategory in which students scored the lowest was curiosity about other cultures. Perhaps the best representation of curiosity about other cultures was in Amira's digital story. She used an anecdote of talking with a tour guide as a catalyst to expand her thinking. Amira demonstrated a genuine interest in the tour guide's life and perspectives as a resident of Australia and asked him questions along the tour. Her digital story recounted what she came to "know about his life and his goals." Here Amira displayed curiosity about another culture beyond her own. Most of the digital stories, however, were absent of narration that evinced curiosity, and as a result, scored low in this aspect of intercultural understanding.

\section{Discussion}

This project developed and explicated a rubric for assessing how students used the DS format to reflect on their study abroad experiences. The digital storytelling assignment in this instance asked students to reflect about the nature of progress and sustainability, which was the academic focus of their study abroad programs. The rubric consisted of three major categories-disciplinary thinking, multimedia coherence, and intercultural understanding. Each of these categories consisted of three subcategories, and rather concrete indicators described four levels of performance within each of the nine subcategories.

The data showed that students attending classes that focused on sustainability did exhibit disciplinary thinking in that domain, as most were able to articulate their knowledge of sustainability and progress. This disciplinary thinking was likely bolstered because the assignment required students to first write a thematic essay, have it reviewed by their peers, and then base the narration of the digital story on that essay. It could be that using a familiar mode of academic discoursesuch as an essay — as the backbone and structure of the digital story facilitated the academic intent of the assignment. Students who adopted more of a personal narrative approach to the concept of progress, framing progress primarily in terms of personal growth, failed to reflect the full scope of the program's disciplinary content.

While content may have been strong, few students expressed clear conclusions about the concept of progress, conclusions that might indicate transformative learning beyond the given context (Mezirow, 1991). Future iterations of these programs might focus more deliberately on how students can incorporate knowledge and experience gained through studying abroad into their lives once they return home.

In relation to multimedia coherence, some students were adept at using the DS form, but most failed to take full advantage of visual and audio resources to support their arguments. The more skilled students in this domain used exciting and memorable images from their experiences abroad, chose music that corresponded to their message, and developed narrative content with an easily discerned thesis. The DS workshop that all students completed during the overseas term provided them with the tools for creating a digital story. Yet most students failed to display creative and sophisticated use of those tools. Ideally, the value added of digital storytelling lies in encouraging students to be more 'present' in the reflection than is usually the case in essay writing (Bruckner, 
2015; Genereux \& Thompson, 2008). Digital storytelling allows “digitally native" students to reflect by using a platform that they routinely use in their daily lives (Czarnecki, 2009). Only one student in the five classes examined, however, was able to deploy DS elements proficiently for academic purposes. Perhaps students could benefit from additional instruction in visual rhetoric (e.g., Hocks, 2003).

Lastly, intercultural understanding was the category least evident in the digital stories. Students did communicate a broad understanding that their perspectives about progress were different than those of the people they encountered but did not as clearly demonstrate other elements such as curiosity about other cultures and understanding of different worldviews. Contrary to the instructional focus that highlighted the sustainability "triple bottom line" of social justice, balanced economic growth, and preservation of natural resources (Bell et al., 2014), most students took the assigned prompt about progress and sustainability to be directed more toward the physical environment rather than encompassing cultural change. In future iterations, program staff and faculty might wish to invest more deliberate effort in cultivating inquiry about human culture and its interaction with the natural environment.

\section{Conclusion}

Our findings show that digital storytelling can be an effective tool for reflection on the study abroad experience, and one that educators should consider using during their overseas programs. The intended disciplinary learning and intercultural understanding were discernible in many of the student productions, though to varying degrees. The adapted rubric also offered a useful mechanism for analyzing the digital stories according to the elements of reflection intended. It seems that the digital story format presents opportunities for students to connect to the content of the assignment in a more personal way by making use of visual content that they are already collecting. This kind of connection promises intensified reflection and possibly a catalyst for transformative learning during study abroad. Digital storytelling can provide a way for students to be more present in their reflection, and enable students to connect to the content on a platform with which they engage daily. We are not suggesting, however, that the digital story be used in place of writing. In the present case, strong essay writing was a significant reason why their digital stories were successful. Instead, digital storytelling can complement other vehicles for reflection.

Our study has several limitations and more research is warranted on the use of digital storytelling in study abroad. We only investigated short-term Maymester classes sited in English speaking cultures. It would be helpful to know whether digital storytelling proves useful in other study abroad contexts such as longer (i.e., semester-length) term classes, and programs taught in world languages. It would also be helpful to know how student's reflections on their study abroad experience change or grow over time. In other words, does the kind of reflection observed immediately after the experience hold true over time, or does it change in any way? Certainly, qualitative interviews with participants re-viewing their digital stories at some remove from the study abroad experience would be instructive.

In the present setting, students were not privy to the multimedia study abroad rubric that we used to score the digital stories. Best practices, in contrast, would encourage students to be active in helping to develop the rubric and have access to it before completing the assignment (Montgomery, 
2002). In future research it would be helpful to ensure that students have access to the rubric ahead of time. As study abroad continues to grow in importance at U.S. colleges and universities, perhaps adding a variety of reflection options such as digital storytelling will strengthen the experience for students and our understanding of the quality of study abroad experiences offered by colleges and universities.

\section{References}

Ash, S. L., \& Clayton, P. H. (2009). Teaching and learning through critical reflection: A tutorial for service-learning students (Instructor version). Raleigh, NC: Ash, Clayton \& Moses..

Association of American Colleges \& Universities. (2014). VALUE rubric development project. Retrieved from https://www.aacu.org/value/rubrics.

Bell, H. L., Gibson, H. J., Tarrant, M. A., Perry III, L. G., \& Stoner, L. (2016). Transformational learning through study abroad: US students' reflections on learning about sustainability in the South Pacific. Leisure Studies, 35(4), 389-405.

Brockington, J. L., \& Wiedenhoeft, M. D. (2006). The liberal arts and global citizenship: Fostering intercultural engagement through integrative experiences and structured reflection. In R. Lewin (Ed.), Handbook of practice and research in study abroad: Higher education and the quest for global citizenship (pp. 117-132). New York, NY: Routledge.

Buckner, M. J. (2015). Investigating digital storytelling as an assessment practice in study abroad programs. (Unpublished dissertation). University of Arizona, Tucson, Arizona.

Churchill, E., \& DuFon, M. A. (2006). Evolving threads in study abroad research. Language learners in study abroad contexts. In E. Churchill and M. DuFon (Eds.), Language learners in study abroad contexts (pp.1-27). Clevedon, UK: Multilingual Matters.

Czarnecki, K. (2009). How digital storytelling builds 21st Century skills. Library Technology Reports, 45(7), 15-19.

Dawson, P. (2017). Assessment rubrics: Towards clearer and more replicable design, research and practice. Assessment and Evaluation in Higher Education, 42(3), 347-360.

Dietrich, J. W., \& Olson, C. (2010). In quest of meaningful assessment of international learning: The development and implementation of a student survey and ePortfolio approach. The Journal of General Education, 59(3), 143-158.

Engle, L., \& Engle, J. (2004). Assessing language acquisition and intercultural sensitivity development in relation to study abroad program design. Frontiers: The Interdisciplinary Journal of Study Abroad, 10, 219-236.

Genereux, A. P., \& Thompson, W. A. (2008). Lights, camera, reflection! Digital movies: A tool for reflective learning. Journal of College Science Teaching, 37(6), 21-31.

Hocks, M. E. (2003). Understanding visual rhetoric in digital writing environments. College Composition and Communication, 54(4), 629-656.

Jakes, D. (2006). Standards-proof your digital storytelling efforts. TechLearning. Retrieved from https://www.techlearning.com/news/standardsproof-your-digital-storytelling-efforts

Lambert, J. (2012). Digital storytelling: Capturing lives, creating community. New York, NY: Routledge.

Lange, E. (2004). Transformative and restorative learning: A vital dialectic for sustainable societies. Journal of Sustainable Tourism, 11, 459-475.

Lee, L. (2011). Blogging: Promoting learner autonomy and intercultural competence through study abroad. Language Learning \& Technology, 15(3), 87-109. Retrieved from http://lit.msu.edu/issues/october2011/abstracts.html\#lee

Li, M. H., Qu, T., \& Petersenn, T. (n.d.) Digital storytelling: Effectiveness on study abroad experiential learning. Landscape Research Record, 5. Retrieved from http://thecela.org/wp-content/uploads/LIQU-PETERSENN.pdf

Lou, K. H., Vande Berg, M., \& Paige, R. M. (2012). Intervening in student learning abroad: Closing insights. In M. Vande Berg, R. M. Paige, \& K. H. Lou (Eds.), Student learning abroad: What our 
students are learning, what they're not, and what we can do about it (pp. 411-420). Sterling, VA: Stylus Publishing.

Marx, H., \& Moss, D. M. (2011). Please mind the culture gap: Intercultural development during a teacher education study abroad program. Journal of Teacher Education, 62(1), 35-47.

McGury, S., Shallenberger, D., \& Tolliver, D. E. (2008). It's new, but is it learning? Assessment rubrics for intercultural learning programs. Assessment Update, 20(4), 6-9.

McLaughlin, J. S., \& Johnson, D. K. (2006). Assessing the field course experiential learning model: Transforming collegiate short-term study abroad experiences into rich learning environments. Frontiers: The Interdisciplinary Journal of Study Abroad, 13, 65-85.

Merriam, S. B. (2009). Qualitative research: A guide to design and implementation. San Francisco, CA: Jossey-Bass.

Mezirow, J. (1990). How critical reflection triggers transformative learning. In J. Mezirow (Ed.), Fostering critical reflection in adulthood (1-20). San Francisco, CA: Jossey-Bass.

Mezirow, J. (1991). Transformative dimensions of adult learning. San Francisco, CA: Jossey-Bass.

Montgomery, K. (2002). Authentic tasks and rubrics: Going beyond traditional assessments in college teaching. College Teaching, 50(1), 34-40.

Moore, J. (2005). Is higher education ready for transformative learning? A question explored in the study of sustainability. Journal of Transformative Education, 3(1), 76-91.

Paige, R. M., Cohen, A. D., Kappler, B., Chi, J. C., \& Lassegard, J. P. (2002). Maximizing study abroad: A students' guide to strategies for language and culture learning and use. Minneapolis, MN: University of Minnesota Center for Advanced Research on Language Acquisition.

Pedersen, P. J. (2010). Assessing intercultural effectiveness outcomes in a year-long study abroad program. International Journal of Intercultural Relations, 34, 70-80.

Perry, L., Stoner, L., Schleser, M., Stoner, K. R., Wadsworth, D., Page, R., \& Tarrant, M. A. (2015). Digital media as a reflective tool: Creating appropriate spaces for students to become introspective. Compare, 45(2), 323-330.

Perry, L., Stoner, L., \& Tarrant, M. (2012). More than a vacation: Short-term study abroad as a critically reflective, transformative learning experience. Creative Education, 3(5), 679-683.

Polanyi, L. (1985). Telling the American story: A structural and cultural analysis of conversational storytelling. Norwood, NJ: Ablex.

Reddy, Y. M., \& Andrade, H. (2010). A review of rubric use in higher education. Assessment \& Evaluation in Higher Education, 35(4), 435-448.

Rhodes, T. L. (2016). The VALUE of assessment: Transforming the culture of learning. Change: The Magazine of Higher Learning, 48(5), 36-43.

Robin, B. R. (2008). Digital storytelling: A powerful technology tool for the 21 st century classroom. Theory in Practice, 47(3), 220-228.

Rodriguez, K. (2010). Digital storytelling in study abroad: Toward a counter-catalogic experience. International Journal of Media, Technology and Lifelong Learning, 6(2), 219-233.

Rubin, D. L., \& Tarrant, M. C. "It changed my life:" Strategies for assessing student learning. In L. Chieffo and C. Spaeth (Eds.), The guide to successful short-term programs abroad (3rd ed., pp. 171182). New York, NY: NAFSA.

Sadik, A. (2008). Digital storytelling: A meaningful technology-integrated approach for engaged student learning. Educational Technology Research and Development, 56(4), 487-506.

Sandars, J., \& Murray, C. (2009). Digital storytelling for reflection in undergraduate medical education: A pilot study. Education for Primary Care, 20(6), 441-444.

Savicki, V., \& Price, M. (2015). Student reflective writing: Cognition and affect before, during and after study abroad. Journal of College Student Development, 56(6), 587-601.

Sullivan, D. F., \& McConnell, K. D. (2018). It's the assignments-A ubiquitous and inexpensive strategy to significantly improve higher-order learning. Change: The Magazine of Higher Learning, 50(5), 16-23. 
Sutton, R. C., Miller, A. N., \& Rubin, D. L. (2007). Research design in assessing learning outcomes of education abroad programs. In M. C. Bolen (Ed.), A guide to outcomes assessment in education abroad (23-60). Carlisle, PA: The Forum on Education Abroad.

Taylor, E. W. (2008, Fall). Transformative learning theory. New Directions for Adult and Continuing Education, 119, 5-15.

Trilokekar, R. D., \& Kukar, P. (2011). Disorienting experiences during study abroad: Reflections of preservice teacher candidates. Teaching \& Teacher Education, 27(7), 1141-1150.

Twombly, S. B., Salisbury, M. H., Tumanut, S. D., \& Klute, P. (2012). ASHE higher education report: Study abroad in a new global century: Renewing the promise, refining the purpose, 38(4). Hoboken, NJ: John Wiley \& Sons.

Walters. C., Charles, J., \& Bingham, S. (2017). Impact of short-term study abroad experiences on transformative learning: A comparison of programs at 6 weeks. Journal of Transformative Education, 15(2), 103-21. doi 10.1177/1541344616670034

Walters, L. M., Green, M. R., Wang, L., \& Walters, T. N. (2011). From heads to hearts: Digital stories as reflection artifacts of teachers' international experience. Issues in Teacher Education, 20(2), 37-52.

\section{Appendix A}

VALUE Discover Abroad Study Abroad Digital Story Rubric

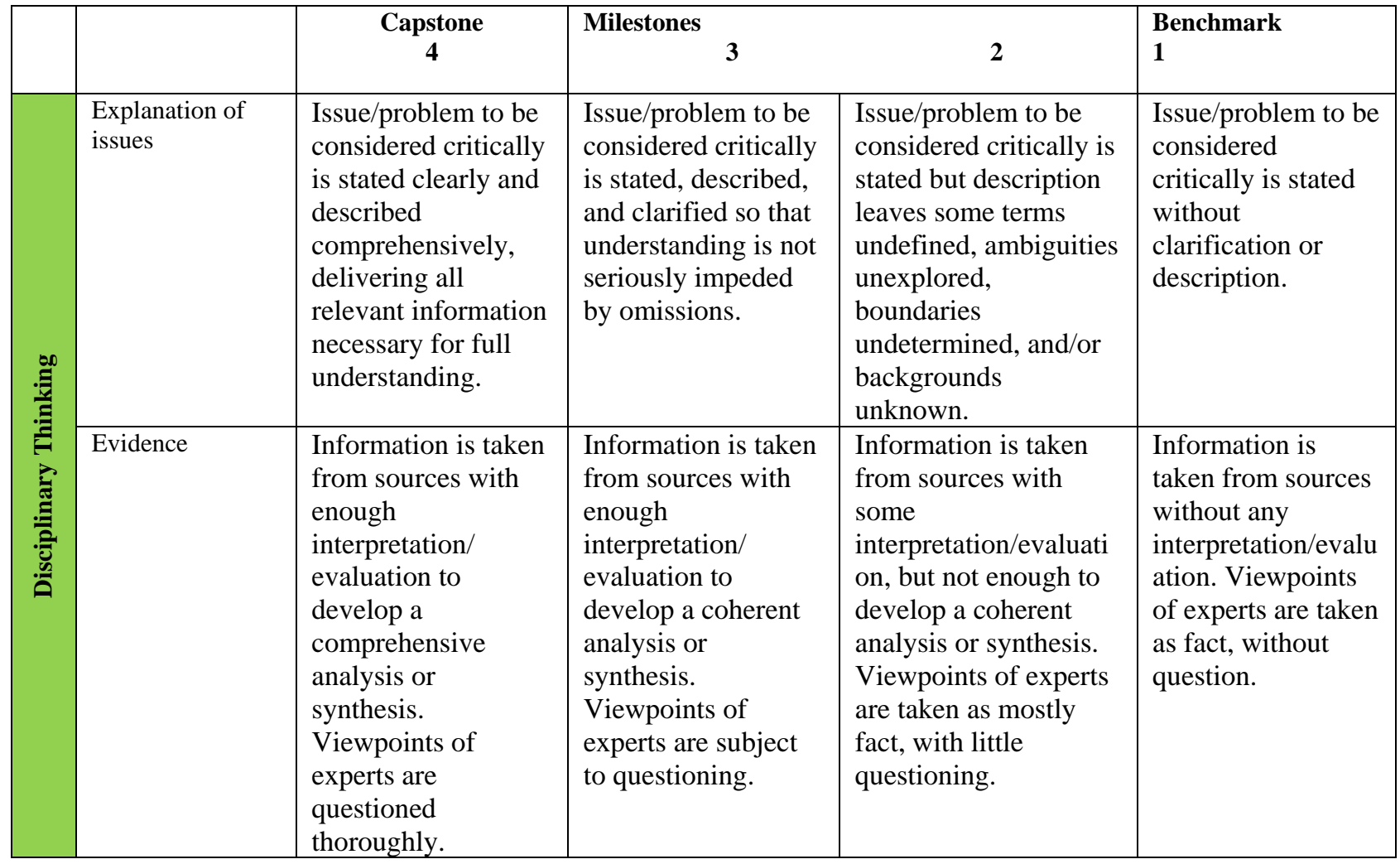




\begin{tabular}{|c|c|c|c|c|c|}
\hline & $\begin{array}{l}\text { Central message } \\
\text { (perspective, } \\
\text { thesis/hypothesis) }\end{array}$ & $\begin{array}{l}\text { Central message } \\
\text { (perspective, } \\
\text { thesis/hypothesis) is } \\
\text { imaginative, taking } \\
\text { into account the } \\
\text { complexities of an } \\
\text { issue. Limits of } \\
\text { position are } \\
\text { acknowledged. } \\
\text { Other points of view } \\
\text { are synthesized } \\
\text { within position. }\end{array}$ & $\begin{array}{l}\text { Central message } \\
\text { (perspective, } \\
\text { thesis/hypothesis) } \\
\text { takes into account } \\
\text { the complexities of } \\
\text { an issue. Other } \\
\text { points of view are } \\
\text { acknowledged } \\
\text { within position. }\end{array}$ & $\begin{array}{l}\text { Central message } \\
\text { (perspective, thesis/ } \\
\text { hypothesis) } \\
\text { acknowledges } \\
\text { different sides of an } \\
\text { issue. }\end{array}$ & $\begin{array}{l}\text { Central message } \\
\text { (perspective, } \\
\text { thesis/hypothesis) } \\
\text { is stated, but is } \\
\text { simplistic and } \\
\text { obvious. }\end{array}$ \\
\hline & $\begin{array}{l}\text { Conclusions and } \\
\text { related outcomes } \\
\text { (implications and } \\
\text { consequences) }\end{array}$ & $\begin{array}{l}\text { Conclusions and } \\
\text { related outcomes } \\
\text { (consequences and } \\
\text { implications) are } \\
\text { logical and reflect } \\
\text { student's informed } \\
\text { evaluation and } \\
\text { ability to place } \\
\text { evidence and } \\
\text { perspectives } \\
\text { discussed in priority } \\
\text { order. }\end{array}$ & $\begin{array}{l}\text { Conclusion is } \\
\text { logically tied to a } \\
\text { range of } \\
\text { information, } \\
\text { including opposing } \\
\text { viewpoints; related } \\
\text { outcomes } \\
\text { (consequences and } \\
\text { implications) are } \\
\text { identified clearly. }\end{array}$ & $\begin{array}{l}\text { Conclusion is logically } \\
\text { tied to information } \\
\text { (because information } \\
\text { is chosen to fit the } \\
\text { desired conclusion); } \\
\text { some related outcomes } \\
\text { (consequences and } \\
\text { implications) are } \\
\text { identified clearly. }\end{array}$ & $\begin{array}{l}\text { Conclusion is } \\
\text { inconsistently tied } \\
\text { to some of the } \\
\text { information } \\
\text { discussed; related } \\
\text { outcomes } \\
\text { (consequences and } \\
\text { implications) are } \\
\text { oversimplified. }\end{array}$ \\
\hline & Organization & $\begin{array}{l}\text { Organizational } \\
\text { pattern of oral and } \\
\text { visual components } \\
\text { is clearly and } \\
\text { consistently } \\
\text { observable, and is } \\
\text { skillful and makes } \\
\text { the content of the } \\
\text { video cohesive. }\end{array}$ & $\begin{array}{l}\text { Organizational } \\
\text { pattern of the oral } \\
\text { and visual } \\
\text { components is } \\
\text { clearly and } \\
\text { consistently } \\
\text { observable within } \\
\text { the video. }\end{array}$ & $\begin{array}{l}\text { Organizational pattern } \\
\text { of the oral and visual } \\
\text { components is } \\
\text { intermittently } \\
\text { observable within the } \\
\text { video. }\end{array}$ & $\begin{array}{l}\text { Organizational } \\
\text { pattern of the oral } \\
\text { and visual } \\
\text { components is not } \\
\text { observable within } \\
\text { the video. }\end{array}$ \\
\hline 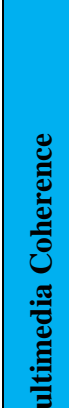 & Visual Content & $\begin{array}{l}\text { Pictures and video } \\
\text { choices are } \\
\text { imaginative, } \\
\text { memorable, and } \\
\text { compelling and } \\
\text { enhance the } \\
\text { effectiveness of the } \\
\text { presentation. They } \\
\text { illustrate and add to } \\
\text { the narration. }\end{array}$ & $\begin{array}{l}\text { Pictures and video } \\
\text { choices are } \\
\text { thoughtful and } \\
\text { generally support } \\
\text { the effectiveness of } \\
\text { the presentation. } \\
\text { They illustrate the } \\
\text { narration. }\end{array}$ & $\begin{array}{l}\text { Pictures and video } \\
\text { choices are mundane } \\
\text { and commonplace and } \\
\text { partially support the } \\
\text { effectiveness of the } \\
\text { presentation. There is } \\
\text { little to no connection } \\
\text { between the visual } \\
\text { content and the } \\
\text { narration. }\end{array}$ & $\begin{array}{l}\text { Pictures and video } \\
\text { choices minimally } \\
\text { support the } \\
\text { effectiveness of the } \\
\text { presentation. Some } \\
\text { of the visual } \\
\text { content is not } \\
\text { appropriate to the } \\
\text { audience. }\end{array}$ \\
\hline$\Sigma$ & $\begin{array}{l}\text { Supporting } \\
\text { Material }\end{array}$ & $\begin{array}{l}\text { A variety of types of } \\
\text { supporting materials } \\
\text { (music, statistics, } \\
\text { quotations, } \\
\text { illustrations, } \\
\text { examples, etc.) } \\
\text { make appropriate } \\
\text { reference to } \\
\text { information or } \\
\text { analysis that } \\
\text { significantly } \\
\text { supports the } \\
\text { presentation. }\end{array}$ & $\begin{array}{l}\text { Supporting materials } \\
\text { (music, statistics, } \\
\text { quotations, } \\
\text { illustrations, } \\
\text { examples, etc.) } \\
\text { make appropriate } \\
\text { reference to } \\
\text { information or } \\
\text { analysis that } \\
\text { generally supports } \\
\text { the presentation. }\end{array}$ & $\begin{array}{l}\text { Supporting materials } \\
\text { (music, statistics, } \\
\text { quotations, } \\
\text { illustrations, examples, } \\
\text { etc.) make appropriate } \\
\text { reference to } \\
\text { information or } \\
\text { analysis that partially } \\
\text { supports the } \\
\text { presentation. }\end{array}$ & $\begin{array}{l}\text { Insufficient } \\
\text { supporting } \\
\text { materials (music, } \\
\text { statistics, } \\
\text { quotations, } \\
\text { illustrations, } \\
\text { examples, etc.) } \\
\text { make reference to } \\
\text { information to } \\
\text { analysis that } \\
\text { minimally supports } \\
\text { the presentation. }\end{array}$ \\
\hline
\end{tabular}




\begin{tabular}{|c|c|c|c|c|c|}
\hline & $\begin{array}{l}\text { Knowledge } \\
\text { Cultural self- } \\
\text { awareness }\end{array}$ & $\begin{array}{l}\text { Articulates insights } \\
\text { into own cultural } \\
\text { rules and biases } \\
\text { (e.g., seeking } \\
\text { complexity; aware } \\
\text { of how her/his } \\
\text { experiences have } \\
\text { shaped these rules, } \\
\text { and how to } \\
\text { recognize and } \\
\text { respond to cultural } \\
\text { biases resulting in a } \\
\text { shift in self- } \\
\text { description). }\end{array}$ & $\begin{array}{l}\text { Recognizes new } \\
\text { perspectives about } \\
\text { own cultural rules } \\
\text { and biases (e.g., not } \\
\text { looking for } \\
\text { sameness; } \\
\text { comfortable with } \\
\text { complexities that } \\
\text { new perspectives } \\
\text { offer). }\end{array}$ & $\begin{array}{l}\text { Identifies own cultural } \\
\text { rules and biases (e.g., } \\
\text { with a strong } \\
\text { preference for those } \\
\text { rules shared with own } \\
\text { cultural group and } \\
\text { seeks the same in } \\
\text { others). }\end{array}$ & $\begin{array}{l}\text { Shows minimal } \\
\text { awareness of own } \\
\text { cultural rules and } \\
\text { biases (even those } \\
\text { shared with own } \\
\text { cultural groups) } \\
\text { (e.g., } \\
\text { uncomfortable with } \\
\text { identifying possible } \\
\text { cultural differences } \\
\text { with others). }\end{array}$ \\
\hline \multirow{3}{*}{ 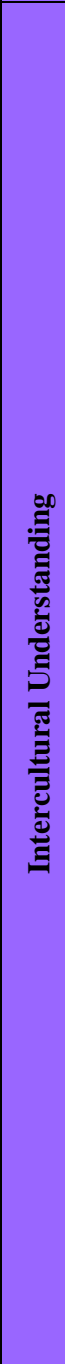 } & $\begin{array}{l}\text { Knowledge } \\
\text { Knowledge of } \\
\text { cultural } \\
\text { worldview } \\
\text { frameworks }\end{array}$ & $\begin{array}{l}\text { Demonstrates } \\
\text { sophisticated } \\
\text { understanding of the } \\
\text { complexity of } \\
\text { elements important } \\
\text { to members of } \\
\text { another culture in } \\
\text { relation to its } \\
\text { history, values, } \\
\text { politics, } \\
\text { communication } \\
\text { styles, economy, or } \\
\text { beliefs and } \\
\text { practices. }\end{array}$ & $\begin{array}{l}\text { Demonstrates } \\
\text { adequate } \\
\text { understanding of the } \\
\text { complexity of } \\
\text { elements important } \\
\text { to members of } \\
\text { another culture in } \\
\text { relation to its } \\
\text { history, values, } \\
\text { politics, } \\
\text { communication } \\
\text { styles, economy, or } \\
\text { beliefs and } \\
\text { practices. }\end{array}$ & $\begin{array}{l}\text { Demonstrates partial } \\
\text { understanding of the } \\
\text { complexity of } \\
\text { elements important to } \\
\text { members of another } \\
\text { culture in relation to } \\
\text { its history, values, } \\
\text { politics, } \\
\text { communication styles, } \\
\text { economy, or beliefs } \\
\text { and practices. }\end{array}$ & $\begin{array}{l}\text { Demonstrates } \\
\text { surface } \\
\text { understanding of } \\
\text { the complexity of } \\
\text { elements important } \\
\text { to members of } \\
\text { another culture in } \\
\text { relation to its } \\
\text { history, values, } \\
\text { politics, } \\
\text { communication } \\
\text { styles, economy, or } \\
\text { beliefs and } \\
\text { practices. }\end{array}$ \\
\hline & $\begin{array}{l}\text { Skills } \\
\text { Empathy }\end{array}$ & $\begin{array}{l}\text { Interprets } \\
\text { intercultural } \\
\text { experiences from } \\
\text { the perspectives of } \\
\text { own and more than } \\
\text { one worldview and } \\
\text { demonstrates ability } \\
\text { to act in a } \\
\text { supportive manner } \\
\text { that recognizes the } \\
\text { feelings of another } \\
\text { cultural group. }\end{array}$ & $\begin{array}{l}\text { Recognizes } \\
\text { intellectual and } \\
\text { emotional } \\
\text { dimensions of more } \\
\text { than one worldview } \\
\text { and sometimes uses } \\
\text { more than one } \\
\text { worldview in } \\
\text { interactions. }\end{array}$ & $\begin{array}{l}\text { Identifies components } \\
\text { of other cultural } \\
\text { perspectives but } \\
\text { responds in all } \\
\text { situations with own } \\
\text { worldview. }\end{array}$ & $\begin{array}{l}\text { Views the } \\
\text { experience of } \\
\text { others but does so } \\
\text { through own } \\
\text { cultural worldview. }\end{array}$ \\
\hline & $\begin{array}{l}\text { Attitudes } \\
\text { Curiosity }\end{array}$ & $\begin{array}{l}\text { Asks complex } \\
\text { questions about } \\
\text { other cultures, seeks } \\
\text { out and articulates } \\
\text { answers to these } \\
\text { questions that reflect } \\
\text { multiple cultural } \\
\text { perspectives. }\end{array}$ & $\begin{array}{l}\text { Asks deeper } \\
\text { questions about } \\
\text { other cultures and } \\
\text { seeks out answers to } \\
\text { these questions. }\end{array}$ & $\begin{array}{l}\text { Asks simple or surface } \\
\text { questions about other } \\
\text { cultures. }\end{array}$ & $\begin{array}{l}\text { States minimal } \\
\text { interest in learning } \\
\text { more about other } \\
\text { cultures. }\end{array}$ \\
\hline
\end{tabular}

